\title{
Co-morbidity associated with fabricated illness (Munchausen syndrome by proxy)
}

\author{
C N Bools, B A Neale, S R Meadow
}

(3) The perpetrator denies the aetiology of the child's illness.

(4) Acute symptoms and signs of illness cease when the child is separated from the perpetrator (almost always the mother).

Hospital case notes of index children were examined for evidence of failure to thrive, nonaccidental injury, inappropriate medication, neglect and fabricated illness, before or at the same time as the identification of the index fabrications. Failure to thrive was recorded when this term was identified in the notes, or when there was evidence that the child had significant problems gaining weight which improved on hospital admission or other change of environment. Non-accidental injury was recorded when this had been decided by a case conference or appeared to be the most probable explanation of injuries in the light of an extended history of each child. Where possible the case notes of all siblings in each family were examined similarly. The circumstances of any deaths were examined. In many cases the general practitioner's notes were also examined. The case notes were examined also for continuing problems after the time of the index fabrication. The latter information was collected for a follow up study which will be published separately.

Initially 62 families were selected from about 100 families in which a child had suffered from the effects of a fabricated illness. They were selected on the basis of their recent address being known and availability for the study (including the fact that we believed we had, or could obtain, comprehensive medical records relating to the index child and siblings). During the course of the investigation it became apparent that we had insufficient information on six families, and therefore this part of the study was limited to 56 families.

\section{Results}

TYPES OF FABRICATION

Patients and methods

We reviewed a large number of cases of Munchausen syndrome by proxy which had been identified over a 13 year period from 1976 to 1988 . This was possible because one of the authors (SRM) had been consulted, by professional colleagues, about cases from many parts of the. UK. The cases met the following four criteria modified from Rosenberg and Meadow' ${ }^{2}$ :

(1) Illness in a child is fabricated by a parent, or someone who is in loco parentis.

(2) The child is presented for medical assessment and care, usually persistently, often resulting in multiple medical procedures.

Dr C N Bools to: Department of Child and Family Psychiatry Royal United Hospital Accepted 12 August 1991
The 56 families were grouped according to the most serious variety of fabrication for the index child in each family. The resulting four groups (smothering, poisoning, seizures, and miscellaneous) are shown in table 1.

For the smothered group ( 15 children; eight boys) the usual story given by the mother was that the child had stopped breathing and went blue (cyanotic/apnoea attacks) or had a fit. The period over which the suffocations occurred ranged from 1-47 months (median 9 months). The number of episodes of suffocation for each child ranged from $2-400$. The median age at discovery was 15 months. 
Table 1 Co-morbidity for 56 index children: the problems before recognition of the index fabrication

\begin{tabular}{|c|c|c|c|c|c|}
\hline \multirow{2}{*}{$\begin{array}{l}\text { Variety of } \\
\text { Munchausen syndrome } \\
\text { by proxy }\end{array}$} & \multirow{2}{*}{$\begin{array}{l}\text { No of } \\
\text { index } \\
\text { children }\end{array}$} & \multicolumn{3}{|l|}{ Problem } & \multirow{2}{*}{$\begin{array}{l}\text { Total No } \\
\text { affected by } \\
\text { problem }\end{array}$} \\
\hline & & $\begin{array}{l}\text { Failure } \\
\text { to thrive }\end{array}$ & $\begin{array}{l}\text { Non-accidental } \\
\text { injury, neglected, } \\
\text { or medicated }\end{array}$ & $\begin{array}{l}\text { Other } \\
\text { fabrications }\end{array}$ & \\
\hline $\begin{array}{l}\text { Smothering } \\
\text { Poisoning } \\
\text { Seizures } \\
\text { Miscellaneous }\end{array}$ & $\begin{array}{l}15 \\
15 \\
14 \\
12\end{array}$ & $\begin{array}{l}5 \\
6 \\
1 \\
4\end{array}$ & $\begin{array}{l}2(2) \\
3(1) \\
4(1) \\
7(3)\end{array}$ & $\begin{array}{r}5 \\
12 \\
10 \\
9\end{array}$ & $\begin{array}{r}8 \\
14 \\
10 \\
9\end{array}$ \\
\hline $\begin{array}{l}\text { Totals } \\
\% \text { Of index children }\end{array}$ & 56 & $\begin{array}{l}16 \\
29\end{array}$ & $\begin{array}{l}16(7) \\
29\end{array}$ & $\begin{array}{l}36 \\
64\end{array}$ & $\begin{array}{l}41 \\
73\end{array}$ \\
\hline
\end{tabular}

Figures in parentheses refer to children also affected by failure to thrive (previous column). 'Other fabrications' refers to symptoms or illnesses in addition to the index fabrication.

The poisonings ( 15 children; eight boys) were carried out with a variety of substances: common salt, salt + hypnotic, lactulose, phenobarbitone, phenytoin, promethazine, 'Campden tablets' (sodium metabisulphite), amitriptyline, imipramine, lorazepam +imipramine + Milk of Magnesia, diazepam+De-Nol+aspirin. The children were usually presented to doctors with drowsiness or were said to have had a fit. In one case laxative administration either maintained or caused diarrhoea. The age of the children at the recognition of the poisoning ranged from 7 months -8 years. Two index children died from the poisonings. Additionally 11 other children (including siblings), classified here in other groups, had received medication. In some cases this had been oversedation by the mother, in other cases young children had taken medicines, not prescribed for them, in laråe doses. For a number of these 'overdoses', hospital admission notes recorded the ingestions as 'accidental'. In hindsight some of these ingestions were probably not accidental.

The 14 children (seven boys) in the third group had stories of seizures fabricated by their mothers, in some cases over many years, leading to extensive inappropriate medication for epilepsy. However, at the time of the discovery, there was no evidence that the mothers had caused direct physical harm to their child.

The 12 children (four boys) in the 'miscellaneous group' had a variety of fabrications imposed on them. These included haematemesis, haematuria, haemoptysis, urinary tract infection, glycosuria, pyrexia (by altering a temperature chart), vomiting, food allergy, and cancer. In two cases skin rashes were directly caused by abrasion.

CO-MORBIDITY FOR INDEX CHILDREN

Concerns recorded by professionals about failure to thrive, non-accidental injury, inappropriate medication, neglect, and additional fabrications, before or at the same time as the recognition of the index fabricated illness, are shown for each of the four groups in table 1 . It can be seen that failure to thrive had been present in almost one third of cases (and in a half of these cases there had additionally been either a non-accidental injury or neglect). In total eight children had actually suffered from a non-accidental injury (with one of these also suffering neglect and one also receiving inappropriate medication), while six other children had suffered from neglect and a further three had been inappropriately medicated (not detailed in table). A large proportion $(64 \%)$ had had more than one problem or illness fabricated. In the poisoned group this was as high as $80 \%$. Overall, for 41 of the 56 index children $(73 \%)$ there had been either failure to thrive, non-accidental injury, inappropriate medication, neglect, or they had been subject to more than one fabrication.

\section{PROBLEMS FOR SIBLINGS}

Forty three of the 56 index children (77\%) had one or more siblings at the time of our investigation (table 2). Detailed records were available for 82 of these 103 siblings; incomplete information was available for another 21 siblings because of lost contact as a result of the child reaching adulthood and moving, or files being missing. We concluded that a large proportion of the siblings (39\%) had themselves been the subject of fabricated illnesses, and $17 \%$ had suffered from either failure to thrive, nonaccidental injury, inappropriate medication, or neglect. Seven siblings had received medication inappropriately.

Thirteen siblings had died and for 11 of these the reason was not medically conclusive at the time. The two deaths with identified causes were due to prematurity and congenital heart disease and occurred at 7 days and 2 months, respectively. One of the other deaths was in the first week of life; the remaining 10 occurred between the ages of 3 months and 18 months (median 10 months). Overall, $43 \%$ of siblings were affected by one or more of these problems; they came from 29 of the $\mathbf{4 3}$ families with more than one child.

\section{Discussion}

Some of the cases reported here have been reported in the literature, most commonly as single case reports, and some were probably included in Rosenberg's comprehensive litera-

Table 2 Morbidity and mortality for 103 siblings from 43 families

\begin{tabular}{|c|c|c|c|c|c|c|}
\hline \multirow{2}{*}{$\begin{array}{l}\text { Variety of } \\
\text { Munchausen syndrome } \\
\text { by proxy }\end{array}$} & \multirow{2}{*}{$\begin{array}{l}\text { Incomplete } \\
\text { data }\end{array}$} & \multirow{2}{*}{$\begin{array}{l}\text { Total } \\
\text { No of } \\
\text { siblings }\end{array}$} & \multicolumn{3}{|l|}{ No of siblings } & \multirow{2}{*}{$\begin{array}{l}\text { Total No } \\
\text { affected }\end{array}$} \\
\hline & & & $\begin{array}{l}\text { Victims of } \\
\text { Munchausen syndrome } \\
\text { by proxy }\end{array}$ & $\begin{array}{l}\text { Failure to thrive, } \\
\text { non-accidental injury, } \\
\text { neglected, or } \\
\text { medicated }\end{array}$ & $\begin{array}{l}\text { Died of } \\
\text { uncertain } \\
\text { cause }\end{array}$ & \\
\hline $\begin{array}{l}\text { Smothering } \\
\text { Poisoning } \\
\text { Seizures } \\
\text { Miscellaneous }\end{array}$ & $\begin{array}{r}0 \\
0 \\
10 \\
11\end{array}$ & $\begin{array}{l}25(12) \\
26(12) \\
30(11) \\
22(8)\end{array}$ & $\begin{aligned} 12 & (8) \\
8 & (6) \\
15 & (8) \\
5 & (4)\end{aligned}$ & $\begin{array}{ll}4 & (3) \\
5 & (4) \\
4 & (2) \\
5 & (4)\end{array}$ & $\begin{array}{l}8(6) \\
3(3) \\
0 \\
0\end{array}$ & $\begin{aligned} 14 & (9) \\
10 & (8) \\
15 & (8) \\
5 & (4)\end{aligned}$ \\
\hline $\begin{array}{l}\text { Totals } \\
\% \text { Of total siblings }\end{array}$ & 21 & $103(43)$ & $\begin{array}{l}40(26) \\
39\end{array}$ & $\begin{array}{l}18(13) \\
17\end{array}$ & $11(9)$ & $\begin{array}{l}44(29) \\
43\end{array}$ \\
\hline
\end{tabular}

Figures in parentheses refer to number of families. 
ture review of 117 cases. $^{3}$ We believe this to be the first systematic study, using original case records, to look at the co-morbidity of victims of fabricated illness and their siblings in a consecutive series of families referred to one centre. Failure to thrive $(29 \%)$ and nonaccidental injury (18\%) were significant associated problems, as were inappropriate medication and neglect. The increased mortality of siblings has been noted before ${ }^{5-8}$ and is confirmed by our study for siblings of smothered and poisoned index children. Most siblings do not die but it is alarming that $39 \%$ were victims of fabricated illnesses themselves and a substantial proportion were also affected by failure to thrive, nonaccidental injury, inappropriate medication, and neglect.

The high morbidity rates may reflect the severity of abuse represented by the index cases. Most fabricated illness involves the mother merely inventing an illness story for the child, without resorting to direct physical action herself. It is relevant that more than half of the index children in this study had suffered from the direct actions of their mothers (by suffocation, poisoning, or skin abrasion) as well as invented false illness stories. It is likely that the underreporting of co-morbidity in previous reports results partly from the problems not being sought systematically, particularly in siblings, and also from the difficulties in obtaining original case records, including the general practitioners' files. In relation to failure to thrive it should be recognised that in some cases the nature of the fabrication caused the chronic ill health, while in others it seemed to be a separate problem, predating the fabrication.

In this study we have identified specific problems before or at the same time as the identified fabricated illness. We have not specifically addressed the issue of emotional abuse which is difficult to identify and describe, especially retrospectively. ${ }^{9}$ Other authors have described the psychological morbidity of the victims of the Munchausen syndrome by proxy in a number of children. ${ }^{10}$ Continuing problems, including new fabrications or other new abuse, as well as emotional or behavioural disturbance in these children are the subject of a separate study.

The high morbidity rates for the siblings almost certainly are an underestimate, particularly as we were unable to obtain full data concerning one fifth of the siblings. Moreover, a number of the siblings, mostly those later in birth order, had been protected by legal orders or were not living with their mothers at the time of our study and so were at reduced risk of abuse. For all these reasons the figures for associated morbidity in the index children and for morbidity in the siblings should be considered as a minimum.

The implications for the management not only of the index children in cases of fabricated illness, but also of the siblings, are clear. In a family where this behaviour has occurred, the risk to all children in the family, of a variety of abuses and neglect, is high. Therefore the relevant professionals, usually the paediatrician, a social worker, and a child psychiatrist, should carry out a detailed assessment, in conjunction with the general practitioner and health visitor, of all the children and the parenting behaviours of mother and father. ${ }^{11-13}$ In order to ensure the safety, and normal physical and emotional development of the children, if they remain in the family, professional involvement will usually be necessary until they are adult and usually will need to be on a statutory basis.

We would like to thank the many paediatricians, general practitioners, and social workers who contributed to this study. Mandy Jones and Mary Jeffrey provided invaluable secretarial support. Brenda Neale and Christopher Bools were supported by support. Brenda Neale and Christopher Bools were supported by grant numbe
Authority.

1 Meadow R. Munchausen syndrome by proxy-the hinterland of child abuse. Lancet 1977;ii:343-5.

2 Meadow R. Munchausen syndrome by proxy. Arch Dis Child 1982;57:92-8.

3 Rosenberg DA. Web of deceit: a literature review of Munchausen syndrome by proxy. Child Abuse Negl 1987; 11:547-63.

4 Meadow R. Letter. Child Abuse Negl 1990;14:289.

5 Pickering $D$. Salicylate poisoning: the diagnosis when its possibility is denied by the parents. Acta Paediatr Scand 1964;53:501-4.

6 Rogers D, Tripp J, Bentovim A, Berry D, Goulding R. Nonaccidental poisoning: an extended syndrome of child abuse. BMF 1976;i:793-6.

7 Rosen CL, Frost JD, Bricker T, Tarnow JD, Gillette PC, Dunlavy S. Two siblings with cardiorespiratory arrest: Dunlavy S. Two siblings with cardiorespiratory arrest: Munchausen syndro

8 Meadow R. Suffocation, recurrent apnoea, and sudden infant death. F Pediatr 1990;117:351-7.

9 Garbarino J. The elusive 'crime' of emotional abuse. Child Abuse Negl 1978;2:89-99.

10 McGuire TL. Psychological morbidity of children subjected to Munchausen syndrome by proxy. Pediatrics 1989;83: $289-92$.

11 Meadow R. Management of Munchausen syndrome by proxy. Arch Dis Child 1984;60:385-93.

12 Department of Health and Social Security and the Welsh Office. Working together. London: HMSO, 1988.

13 Black D, Wolkind S, Harris Hendriks J, eds. Child psychiatry and the law. London: Gaskell, 1989. 